Male Call

New Americanists

A SERIES EDITED BY DONALDE. PEASE 


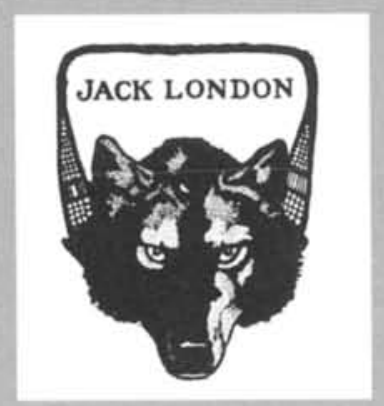




\title{
MALE CALL
}

\section{BECOMING JACK LONDON}

\author{
Jonathan Auerbach
}

Duke University Press Durham and London 1996 
C 1996 Duke University Press

All rights reserved Printed in the United States of America on acid-free paper $\infty$

Designed by Cherie H. Westmoreland

Typeset in Plantin with Pabst display by Keystone Typesetters, Inc.

Frontispiece/cover art: Wolf-head logo designed in 1904 by

Ernest James Cross for use on Jack London's bookplates. Courtesy of

I. Milo Shepard and Kenwood Vineyards.

Library of Congress Cataloguing-in-Publication Data

appear on the last printed page of this book. 
To my father and the memory of my mother:

Good Comrades 
